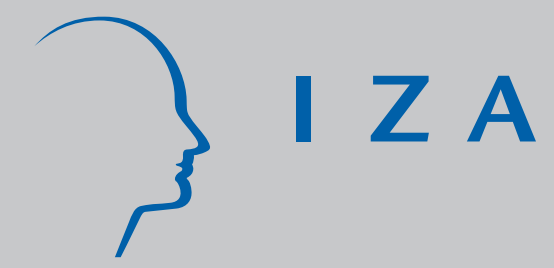

IZA DP No. 1208

On the Negative Relationship between Labor Income Uncertainty and Homeownership:

Risk Aversion vs. Credit Constraints

Luis Diaz-Serrano

J uly 2004 


\title{
On the Negative Relationship between Labor Income Uncertainty and Homeownership: Risk Aversion vs. Credit Constraints
}

\author{
Luis Diaz-Serrano \\ National University of Ireland, Maynooth, \\ CREB, Universitat de Barcelona and IZA Bonn
}

Discussion Paper No. 1208

July 2004

IZA

P.O. Box 7240

53072 Bonn

Germany

Phone: +49-228-3894-0

Fax: +49-228-3894-180

Email: iza@iza.org

\begin{abstract}
Any opinions expressed here are those of the author(s) and not those of the institute. Research disseminated by IZA may include views on policy, but the institute itself takes no institutional policy positions.

The Institute for the Study of Labor (IZA) in Bonn is a local and virtual international research center and a place of communication between science, politics and business. IZA is an independent nonprofit company supported by Deutsche Post World Net. The center is associated with the University of Bonn and offers a stimulating research environment through its research networks, research support, and visitors and doctoral programs. IZA engages in (i) original and internationally competitive research in all fields of labor economics, (ii) development of policy concepts, and (iii) dissemination of research results and concepts to the interested public.
\end{abstract}

IZA Discussion Papers often represent preliminary work and are circulated to encourage discussion. Citation of such a paper should account for its provisional character. A revised version may be available on the IZA website (www.iza.org) or directly from the author. 


\title{
ABSTRACT
}

\section{On the Negative Relationship between Labor Income Uncertainty and Homeownership: Risk Aversion vs. Credit Constraints}

Barriers to homeownership have traditionally been an important research and policy issue. In particular, the role of income volatility and credit constraints have been one of the main focuses in this concern. In this paper we test for the first time whether the underlying nature behind the negative effect of income uncertainty on the owner-occupancy propensities is driven by risk aversion, as it is assumed in most of the theoretical models, or on the contrary it is driven by credit constraints. The former question emerges from the plausible assumption that households facing higher income volatility are also expected to face borrowing constraints. To disentangle this puzzle, we use an unusually rich data coming from the Italian Survey of Household Income and Wealth carried out by the Bank of Italy. Our results confirm that in Italy both labor income uncertainty and credit constraints exert a significant negative effect on the probability of homeownership. Our main findings indicate that the negative relationship between labor income uncertainty and the owner-occupancy propensities are just driven by households' risk aversion, while credit constraints play no role.

JEL Classification: D1, R0, J0

Keywords: homeownership, income uncertainty, credit constraints, risk aversion

\author{
Luis Diaz-Serrano \\ Department of Economics \\ National University of Ireland \\ Maynooth, Co. Kildare \\ Ireland \\ Email: luis.diaz@may.ie
}




\section{Introduction}

Promoting homeownership has historically been one of the goals in most developed economies, since owning one's dwelling is not only a signal of personal success but also one of the most important ways of wealth accumulation. In this sense, the "welfare state" that characterize all the UE countries have led governments to adopt policies facilitating the home acquisition that range from important tax deductions for homebuyers to the public provision of affordable dwellings addressed to low-income households. Nevertheless, it should be noted that the fullfilment of the better policy is conditional on the limitted public resources and the excess of demand from less favored population strata. Moreover, even for non low-income households owning their dwellings cannot be affordable at all since they have to undertake very aggressive levels of indebtedness. Because of this, household's income and credit constraints have become the most important variables affecting the tenure decision. Given that financing the purchase of one's dwelling involves regular monthly payments during 2535 that represents a high share of household's income, uncertainty in household's income becomes as important as the level of income itself. Thus, income uncertainty also constitutes one of the most important barriers to access homeownership.

During the past decade, the effects of income uncertainty and household credit constraints on homeownership have received considerable attention by economists. However, the joint effect of both factors on the housing tenure decisions still remains unexplained. Theoretical models incorporating the effect of income uncertainty on homeownership tend to provide ambiguous results (e.g. Turnbull et al. 1991, Fu 1995 or Ortalo-Magne and Rady 2002). Income uncertainty is reported to have a negative, null or even a positive effect depending on the assumptions underlying each model. However, despite the absence of a consensus in the theoretical literature, the scarce empirical evidence finds an unambiguous negative effect of income uncertainty on the probability of homeownership (Haurin and Gill 1987, Haurin 1991, and Robst et al. 1999, in the US, and Diaz-Serrano 2004, in Germany and Spain).

In all theoretical models, income uncertainty is introduced by assuming any type risk of aversion. This assumption is, of course, more than plausible, since the "fear" of a potential future mortgage default that a risk averse household facing increasing income uncertainty might experience, and the personal failure it involves, are arguments strong enough to accept risk aversion as the main driver of the negative effect of income uncertainty on homeownership. But on the other hand, since lending institutions are also averse to mortgage defaults, the fact that these households might also suffer credit constraints seems a very 
plausible alternative explanation for this negative relationship. The negative relationship between household's credit quality constraints and the propensity to own is also well documented in the empirical literature (e.g. Linneman and Wachter 1989, Haurin et al. 1997, Quercia et al. 2003, and Barakova et al. 2003 in the US, or Bourassa 1995, in Australia) ${ }^{1}$.

During the 1990s, the banking industry has devoted a great effort to design mortgage products addressed to reduce borrower's credit barriers. These range from important innovations in affordable mortgage lending, that reduces down payment to a minimum amount or to zero, to mortgage protection tools that allow borrowers to insure their periodical mortgage payments against unexpected income shocks, as for example temporary unemployment. The latter specially addressed to mitigate the devastating effect that income uncertainty exerts to access homeownership, with a low success though ${ }^{2}$.

In order to design efficient public policies or suitable mortgage products it this concern, one should know the real nature of the negative relationship between income uncertainty and the propensity to owner-occupancy. If this negative relationship is driven by credit constraints, further efforts to reduce credit barriers by lending institutions might promote higher owning-occupancy rates. However, if such a negative relationship is driven by households' risk aversion, policies addressed to improve the labor market or to the design of more suitable insurance mortgage products should be required. In this sense, it would be not a question of affordability but that households feel "safe" against unexpected shocks in income, since very often more volatile incomes are not necessarily associated to low-incomes, and has more to do with demand shocks that cause fluctuations in income ${ }^{3}$.

We should note that the literature on income uncertainty and credit quality constraints as a barrier to homeownership is focused on the US. Therefore, besides disentangling the puzzle behind the negative effect of income uncertainty, which is in itself motivating enough, we also aim to provide some additional international evidence on the effect of both income volatility and credit constraints on the owner-occupancy propensities. To cover these lacks, we use an unique and unusually rich data set coming from the Survey of Household Income and Wealth (SHIW) carried out by the Bank of Italy over a representative sample of Italian Households.

\footnotetext{
${ }^{1}$ See Rosenthal (2002) for an extensive overview of this literature.

2 There is a wide range of empirical studies that report the failure of such a mortgage payment protection products in the UK. Short variety of risks covered and not affordable premiums are, among others, the main reasons why households most at income ris $\mathrm{k}$ are not the main undertakers of such an insurance products (see e.g. Pryce and Keoghan, 2002).

3 Diaz-Serrano (2004) provides theoretical and empirical support that households located in positively skewed income distributions are more likely to be homeowners. Opposite to risk (variance), negative skewness is taken as a measure of safety in income.
} 
The remainder of the paper is structured as follows. In section 2 we develop a simple formula that highlights the pivotal role of risk aversion on the tenure decision in the presence of labor income uncertainty. Section 3 describes the data set and the empirical framework. Section 4 presents the empirical results. And, section 5 summarizes and concludes.

\section{Labor income uncertainty and risk aversion: a simple formula}

The decision of homeownership is usually modeled as a function of household income, owning costs compared to renting costs, and a set of demographic variables (age, household size, etc.). In this section we develop a simple formula that also accounts for the effect of labor income uncertainty in the housing tenure choice, we specify a household utility function that depends on owning and renting costs and labor income. Labor income is assumed to be additively decomposable between a deterministic and a stochastic component. For the sake of simplicity, we assume no uncertainty in the rental market ${ }^{4}$, and that owning and renting are mutually exclusive options. A household will decide to buy rather than to rent if the expected utility of owning during the tenure period $T$ is greater than that the expected utility of renting

$$
E \int_{0}^{T} U\left(\tilde{P}_{O}, w_{i t}\right) e^{-\rho t} d t \geq E \int_{0}^{T} U\left(\tilde{P}_{R}, w_{i t}\right) e^{-\rho t} d t
$$

where $U(\cdot)$ is the indirect utility associated with owning or renting, $\tilde{P}_{O}$ is the real cost of owning, $\tilde{P}_{R}$ is the real cost of renting, the term $\rho$ is the household's subjective rate of time preference. The utility function satisfies $U_{P}^{\prime}<0, U_{P}^{\prime \prime}>0, U_{y}^{\prime}>0$ y $U_{y}^{\prime \prime}<0$, and $w_{i}$ is the labor income for household $i$, which is assumed to be

$$
w_{i t}=y_{i}+\varepsilon_{i t} \text {. }
$$

In expression (2), $y_{i}$ is "permanent income" and $\varepsilon_{i t}$ is a random term picking up shocks in income due to market forces. We assume that $E\left(\varepsilon_{i t}\right)=0, E\left(\varepsilon_{i t}\right)^{2}=\sigma_{\varepsilon}^{2}$ and $E\left(w_{i t}\right)=y_{i}$. Future changes in the permanent income are perfectly foreseeable by individuals, whereas random shocks captured by $\varepsilon_{i t}$ are only known after their realization.

\footnotetext{
${ }^{4}$ This assumption does not alter our key result.
} 
Let $E\left(\tilde{P}_{O}\right)=\bar{P}_{O}$ and $E\left(\tilde{P}_{R}\right)=\bar{P}_{R}$. After applying multivariate Taylor series expansion up to the second order around $\bar{P}_{O}$ and $y$ on the left-hand-side in (1), and up to the first order around $y$ and the point where the real cost of renting equalizes the expected price of owning $\left(\tilde{P}_{R}=\bar{P}_{O}\right)$ on the right-hand-side, and rearranging we get

$$
\frac{1}{2} \alpha\left(\lambda_{2} \sigma_{P}^{2}-\sigma_{\varepsilon}^{2}\right)-\lambda_{1}\left(\tilde{P}_{R}-\bar{P}_{O}\right) \geq 0
$$

where $\sigma_{P}^{2}=E\left(\tilde{P}_{O}-\bar{P}_{O}\right)^{2} \quad$ is the uncertainty (variance) of owner-occupancy costs, $\lambda_{1}=U_{P}^{\prime} / U_{y}^{\prime}<0$ is the marginal rate of substitution, $\lambda_{2}=U_{P}^{\prime \prime} / U_{y}^{\prime \prime}<0$ and $\alpha=U_{y}^{\prime \prime} /-U_{y}^{\prime}$ is the household's absolute risk aversion (Pratt, 1964).

Expression (3) highlights the pivotal role of risk attitudes $(\alpha)$ in the housing tenure decision. The decision of owner-occupancy crucially depends on the degree of risk aversion $\alpha$, and the difference between real renting costs and the expected owner-occupancy prices, $\left(\tilde{P}_{R}-\bar{P}_{O}\right)$. When households are risk neutral $(\alpha=0)$, the tenure decision only depends on the difference between real renting costs and expected owning costs, and uncertainty plays no role. However, if households are risk averse $(\alpha>0)$, increasing uncertainty in labor income $\left(\sigma_{\varepsilon}^{2}\right)$ and in owner-occupancy costs $\left(\sigma_{P}^{2}\right)$ will exert a negative effect on the probability of homeownership. Only if the gap between renting and owner-occupancy costs is positive $\left(\tilde{P}_{R}>\bar{P}_{O}\right)$ and high enough the effect of risk aversion and uncertainty would be neutralized. Nevertheless, this circumstance is very unlikely.

One situation that might obscure the negative relationship between income uncertainty and homeownership under the assumption of risk aversion is the existence of credit quality constraints. It is plausible to expect that households facing increasing income uncertainty could be also credit constrained. Therefore, in addition to the aversion of these households to undertake aggressive levels of indebtedness, it might be plausible that lenders are also reluctant to fund these households. To what extent which of both situations drives the negative effect of income uncertainty on homeownership requires from empirical work. 


\section{The data and empirical framework}

The data we use in our study comes from the Survey of Household Income and Wealth (SHIW). It is a panel survey (annual from 1977 to 1987 and biannual from 1989 to 2000) carried out by the Bank of Italy, and contains detailed information on household characteristics, employment, income, assets, financial habits, the type of home tenure and several questions regarding the ownership and lending conditions. In addition, starting from 1995, the survey also includes rotatory questions addressed to the study of specific issues. For our purposes, the 1995 and 2000 waves contain questions addressed to the household heads that allow us to construct a measure of individual risk aversion ${ }^{5}$. We use the panel from 1989 to 2000 to estimate income uncertainty and the 1995,1998 and 2000 waves to evaluate credit quality constraints and to estimate reduced form equations of the probability of homeownership. In table 1 we show a description of the variables used in the empirical analysis.

Table 1 around here

\subsection{Measuring household borrowing constraints}

To measure to what extent a household is credit constrained we follow Linneman and Wachter (1989). Taking the same notation they used, threshold house values that a household should aim according to income constraints $\left(V^{I}\right)$, and wealth constraints $\left(V^{W}\right)$ are:

$$
V^{I}=0.35 \frac{I}{r}, \quad V^{W}=5 \cdot W
$$

where $r$ is the mortgage interest rate, $I$ is the annual household income, and $W$ is net household wealth. Since house values are only observed for homeowners, I use a subsample of unconstrained homeowners, those with observed dwelling purchase bellow $85 \%$ of both $V^{I}$ and $V^{W}$, to estimate the following housing demand equation

$$
V_{i}^{*}=X_{i} \beta+u_{i}
$$

\footnotetext{
${ }^{5}$ Guiso and Paiella (2001) used the 1995 questions to look at risk attitudes across different Italian population groups, and Brunello (2001) also employed this information to study of the returns to education in Italy.
} 
where $X$ is a vector of household characteristics which also includes house preferences, and $u_{i}$ is a random error term. The linear estimation by OLS of the preferred housing value is reported in table 2. Most of the variables considered are significant at $1 \%$ or better. Both household income and the age of the household head show a positive but decreasing effect. Higher preferred house values are observed in the North-East of Italy and the Islands, and it is decreasing with the city size. It is worth noting the significant positive effect of the renting costs respect to owning costs, i.e. households show higher house preferred values in regions where the renting costs are increasing in relation to owning costs.

Table 2 around here

After estimating equation (5), we use $\hat{\beta}$ to impute a $\hat{V}_{i}^{*}$ to each household, either homeowner or renter. Hence, we assume that a household suffer income $(I B C)$ or wealth borrowing constraints $(W B C)$ if $\hat{V}_{i}^{*}>0.9 \cdot V^{I}$ or $\hat{V}_{i}^{*}>0.9 \cdot V^{W}$, respectively. From the previous indicators we also define a two more general indicators; $B C l=1$ for those that at least is constrained in either one of the categories $W B C$ or $I B C$; and $B C 2=1$ indicating whether the household is constrained in both $W B C$ and $I B C$.

Our dataset also provides some questions that allow us to directly measure borrowing constraints in the same fashion as in Rosenthal (2002). These questions are:

C54. During the last 12 months did your household apply to a bank or a financial company for a loan or a mortgage?

C55. Was the application granted in full, in part or rejected?

C56. During the last 12 months did you or another member of your household consider the possibility of applying to a bank or a financial company for a loan or a mortgage but then change his/her mind thinking that the application would be rejected?

From answers to C54-C56 we create a dummy variable that takes 1 if the loan was denied or just partly granted, or if any member refrained from applying concerned of being turned down. We call this direct proxy of being credit constrained DCC. Table 3 shows some summary statistics on $I B C, W B C$ and $B C 2$. As expected, renters are remarkably more wealth and income constrained than owners. However, we find an unusual lower percentage of renters that are income constrained, $51 \%$ vs. the $75 \%$ observed in e.g. Australia (Bourassa, 
1995). We find that these renters that are relatively low income constrained are mainly concentrated in the North-West of Italy (the richest region) and in bigger cities $(500,000$ inhabitants or more). As we show in table 2, in these more industrialized locations households also report smaller preferred house values than in the rest of the country. Due to the higher mobility that characterizes more industrialized locations, in these regions and cities households might probably have higher preference for renting, independently of their income levels.

Table 3 around here

\subsection{Measuring income uncertainty}

Following Robst et al. (1999) and Diaz-Serrano (2004) income uncertainty will be measured using the household head's net annual labor income. There are several reasons to sustain that this source of income is the main determinant of homeownership. Firstly, it is the main component of the household's net disposable income, and secondly, it also tends to be more stable than other sources of income. In Italy, the share of the household head labor income in the overall household income has been moving around 60-70\% between 1986 and 2000. Hence, because of its more transitory nature, the remaining 30-40\% of the household income composed by other members' wages, assets or transferences are not so relevant in the homeownership decision.

According to equation (2), we model household head's labor income as

$$
\ln \left(w_{i t}\right)=X_{i t} \beta+u_{i}+\varepsilon_{i t},
$$

where the subscripts $i$ and $t$ indexes households and time, respectively; $\ln \left(w_{i t}\right)$ is the natural logarithm of the household head annual labor income; $X_{i t}$ is a set of explanatory variables referring to the household head; $u_{i}$ is an intrinsic individual time-constant shock in earnings ${ }^{6}$; $\varepsilon_{i t}$ is a time-varying random shock in earnings; and $\beta$ is the set of parameters to be estimated. We estimate equation (6) by means of a panel data model with random effects (see Hsiao 1986, Ch. 4) using the rotatory unbalanced panel $^{7}$ covering the period 1986-2000. Table 2

\footnotetext{
${ }^{6}$ This term picks up the individual heterogeneity and it represents a permanent shock in labor income. The panel data model (5) allows separate this specific-individual effect from the transitory shocks $\varepsilon_{i t}$.

${ }^{7}$ Given this random rotatory nature of the panel, attrition bias is not present.
} 
shows the estimation of the labor income equation (5). All the explanatory variables are highly significant and have the expected signs.

The term $y_{i t}=X_{i t} \beta+u_{i}$ represents the permanent income ${ }^{8}$, whereas the term $\varepsilon_{i t}$ is associated with transitory shocks in labor income. As in Robst et al. (1999) and Diaz-Serrano (2004), income uncertainty would be estimated using the time-varying component of the estimated residuals in equation (6) as follows 9 :

$$
\hat{\sigma}_{\varepsilon i}^{2}=\frac{1}{T} \sum_{i=1}^{T}\left\{\exp \left(\hat{\varepsilon}_{i t}\right)-\hat{\varepsilon}_{i}\right\}^{2}
$$

where the exponential transformation is used in order to transfer back $\hat{\varepsilon}_{i t}$ to money metric. Table 4 reports the level of income uncertainty for selected population groups. As expected, renters face, on average, about $42 \%$ more uncertainty than owners, 0.37 vs. 0.26 , respectively. It is noteworthy that labor income uncertainty is decreasing with age up to the age of 50 for owners and increasing for renters. In wealthier regions (North), income uncertainty is markedly lower than in the poorer (South and Islands). In these regions the gap in income uncertainty between owners and renters is also increasing. Moreover, for the rest of the household head characteristics the levels of income uncertainty display a reverse pattern between owner and renters. These results indicate that tenure choices are strongly influenced by this variable.

\section{Table 4 around here}

\subsection{Measuring risk aversion}

Our measure of risk-aversion is based on individual responses to the following question:

"You are offered the opportunity of acquiring a security permitting you, with the same probability, either to gain 10 million lire $(\cong € 5,200)$ or to lose all the capital invested. What is the most you are prepared to pay for this security?"

\footnotetext{
${ }^{8}$ The explanatory variables in $X_{i t}$ are assumed to generate systematic labor income differentials. Individuals know the unit price of these variables in the labor market, and hence they can foresee future changes in their permanent income

9 In Diaz-Serrano (2004) there is an extensive discussion about why it is more suitable to compute income uncertainty on the residuals rather than using the observed labor income.
} 
Using a Taylor series approximation to the utility function Hartog et al. (2002) obtain the following approximate expression for the Arrow-Pratt measure of absolute risk aversion (ARA):

$$
A R A_{i}=\frac{\left(\lambda Z-P_{i}\right)}{\left[\frac{1}{2}\left(P_{i}^{2}+\lambda Z^{2}\right)-\lambda P_{i} Z\right]},
$$

where $\lambda$ is the probability of wining this "lottery", $Z$ is the "prize" and $P$ is the amount that individuals are willing to play. According to this formula, individuals who are willing to pay 5 million lire $(\mathrm{P} \cong € 2,600)$ are assumed to be risk neutral, bellow this value individuals are assumed to be risk averse (ARA $>0)$, and above this value $(A R A<0)$, risk lovers. In case of risk neutrality we get $\mathrm{ARA}=0$, for maximum risk aversion $(\mathrm{P}=€ 0), \mathrm{ARA}=2 / \mathrm{Z}$, and for maximum risk loving $(\mathrm{P} \cong € 5,200),(\mathrm{ARA}=-2 / \mathrm{Z})$.

In total 8,135 household heads answered the questionnaire in 1995 and 3,933 did so in 2000. This corresponds to 12,068 individuals, from who 950 participated in both waves. We show a summary statistics in table 5. The distribution of individual risk aversion in our sample report a similar distribution to that observed in Guiso and Paiella (2001), and Hartog et al. (2002) for The Netherlands, though Dutch tend to be a bit more risk averse than Italians. Considering just individuals with a positive reservation price, we get that in 1995 about $76.5 \%$ of the respondents were risk-averse, $17 \%$ were risk-neutral and $6.5 \%$ were risk-lovers. However, in 2000 risk aversion moved up to $92.4 \%$, and risk neutrality and risk loving felt up to 6.7 and $0.85 \%$, respectively.

\section{Table 5 around here}

Measuring risk aversion, based on hypothetical lottery games, is often criticized. Some researchers doubt about whether such questions can be answered in a meaningful way, and whether the answers can really be correlated with real risk undertaking propensities (e.g. risk taken in portfolio investments). To deal with this criticism, we test the performance of our risk aversion measure $(A R A)$ with two individual decisions that are assumed to be strongly dependent on the degree of risk aversion, as self-employment and investment in risky assets (bonds, shares and mutual funds overall household's portfolio). Results are presented in table 6. 
Table 6 around here

We use three different models to validate the ARA measure with the investment in risky assets. First, a probit model where the endogenous variable is a dummy that equals 1 if the household has risky assets in the portfolio. Second, a generalized linear model on the percentage of risky assets in the overall portfolio. And third, a Tobit model on the total amount invested in risky assets with truncation at zero. In the case of self-employment we use a probit specification. In all cases the measure of risk aversion showed an excellent performance with a negative and highly significant effect (at $1 \%$ or better).

\subsection{Econometric model}

To explore the effect of a variable of interest on the probability of homeownership, a probit or a logit model can be used. The binary decision is modeled in the following way

$$
Y_{i}^{*}=X_{i} \beta+R_{i} \gamma+C C_{i} \delta+\varepsilon_{i}
$$

where $Y_{i}^{*}$ is a latent variable representing the utility of being owner-occupier, with the following binary outcome; $Y_{i}=1$ if $Y_{i}^{*}>0$, and $Y_{i}=0$ if $Y_{i}^{*} \leq 0, X_{i}$ is a set of households and location characteristics, $R_{i}$, as our variable of interest, is labor income uncertainty, $C C_{i}$ is a variable reflecting whether the household is credit constrained, and $\varepsilon_{i}$ is a random error term.

From equation (9) we should expect $\delta<0$ (see e.g. Linneman and Wachter 1989, Bourassa 1995, Haurin et al. 1997, and Barakova et al. 2003). However, the traditional estimation of a univariate probit model will provide an inconsistent estimation for $\beta, \gamma$, and $\delta$ if the error term in a choice equation where $C C_{i}$ is endogenous is correlated with $\varepsilon_{i}$ (see Woolbridge 2002, Ch. 15 , p. 477). In our case, the way to avoid this potential source of inconsistency is to estimate a simple bivariate probit on the probability of homeownership and the probability of being credit constrained, where the former is an explanatory variable in the homeownership equation and simultaneously endogenous in the other equation.

Previous empirical research (Haurin 1991, Robst et al. 1999, and Diaz-Serrano 2004) shows that $\gamma_{1}<0$. Testing to what extent such a result is driven by households risk aversion or by borrowing constraints, requires to estimate equation (9) for different population groups 
according to their status as borrowing constrained or risk averse. Therefore, following with the previous assumptions our model consists in two simultaneous equations

$$
\begin{gathered}
Y_{i 1}^{*}=X_{i 1} \beta_{1}+\varepsilon_{i 1} \\
Y_{i 2}^{*}=X_{i 2} \beta_{2}+R_{i 2} \gamma_{2}+\varepsilon_{i 2}
\end{gathered}
$$

where $Y_{i 1}{ }^{*}$ is the latent variable indicating the propensity to be borrowing constrained or risk averse, and $Y_{i 2}{ }^{*}$ is the latent indicator regarding the propensity of homeownership. Given that the decision to be owner-occupier for borrowing constrained or risk averse households can be only observed if they indeed show this propensity previous to the tenure status decision, we face both censoring and observation rule for $Y_{i 1}$ and $Y_{i 2}$. Therefore, to avoid sample selection bias, we need to control for correlation between the error terms and the sequence of choices in order to estimate parameters in the equation-system $(10)^{10}$. For each tenure outcome we have three types of observation: being credit constrained; being homeowner; and not being homeowner. Analogously, we can draw the same sequence in the case that the first latent indicator $\left(Y_{i l}{ }^{*}\right)$ refers to the propensity of being or not risk averse. The unconditional probabilities of this decision tree are given by:

$$
\begin{aligned}
& P\left(Y_{i 1}=1 \cap Y_{i 2}=1\right)=\Phi_{2}\left(X_{i 1} \beta_{1}, X_{i 2} \beta_{2}, \rho\right) \\
& P\left(Y_{i 1}=1 \cap Y_{i 2}=0\right)=\Phi_{2}\left(X_{i 1} \beta_{1},-X_{i 2} \beta_{2},-\rho\right) \\
& P\left(Y_{i 1}=0\right)=\Phi\left(-X_{i 1} \beta_{1}\right)
\end{aligned}
$$

where $\Phi$ and $\Phi_{2}$ denote the univariate and bivariate standard normal cumulative distribution functions, respectively. And, the resulting log-likelihood function is given by

$$
\log L=\sum_{\substack{Y_{1 i}=1 \\ Y_{2 i}=1}} \log \Phi_{2}\left(X_{i 1} \beta_{1}, X_{i 2} \beta_{2}, \rho\right)+\sum_{\substack{Y_{1} i=1 \\ Y_{2 i}=0}} \log \Phi_{2}\left(X_{i 1} \beta_{1},-X_{i 2} \beta_{2},-\rho\right)+\sum_{Y_{1 i}=0} \log \Phi\left(-X_{i 1} \beta_{1}\right)
$$

To evaluate differentials in the effect of labour income uncertainty on the probability of homeownership for our groups of interest, we estimate the system equation (8) keeping constant the tenure outcome $Y_{i 2}=1$ (owner-occupier) and replacing $Y_{i l}=1$ for each group: risk averse, non risk averse, credit constrained, and non credit constrained.

\footnotetext{
${ }^{10}$ The bivariate probit with sample selection is also used in Rosenthal (2002).
} 
Finally, to estimate the system of equations (10), with and without sample selection, we restrict our sample to homeowners who bought their dwelling after 1989 and still have outstanding mortgage payments. The presence in the sample of households that have purchased their dwelling too many years ago or do not outstand any mortgage might obscure the relationship between labor income uncertainty and the probability of homeownership. We use a pooled cross-section sample for the years 1995, 1998 and 2000. For the individuals with responses in more than one wave we select the last wave they have participated.

\section{Econometric results}

Table 7 and 8 report the econometric estimation on the probability of homeownership. Table 7 focuses on the univariate and simple bivariate probit estimations to evaluate the effect of labor income uncertainty and credit constraints on the probability of homeownership in the full sample. Recall that given the nonlinear nature of the univariate and bivariate probit model, the estimated coefficients lack of any economic interpretation and are just used to determine the sign of the relationship. However, at this stage of the empirical results is what we are interested for.

The credit constraint equation only appears in the bivariate probit model and it is included mainly to avoid the inconsistency of the parameters in the owner-occupancy equation arising from the non-null correlation between the error terms in both equations. Therefore, we are not paying too much attention to the results coming this equation. Note that correlation between both equations has resulted to be highly significant. This equation includes a set of dummy variables collecting the effect of outstanding bank debts. We find that bank debts for the purchase of real goods (e.g. jewlery) and motor vehicles (e.g. cars) are not significant. One might expect that, on average, households usually require from borrowing for the purchase of luxury goods, therefore, the null effect of this type of debt should not be surprising. On the contrary, households that need borrowing to purchase less expensive goods as electrical appliances or non-durable goods are more likely to be credit constrained. Households with older household heads and with more dependent members (without earnings) have higher propensity to be credit constrained. Family income, education of the household head and his/her self-employment status exersts a negative effect on such a propensity.

Recall that the main findings concern the owner-occupancy equation. Consider first the role of the credit constraints. Consistent with the previous evidence, we find that in Italy 
credit constraints exert a significant negative effect on the probability of homeownership. This result remains for the differents measures considered, to be either income or wealth constrained $(B C 1)$, to be both income and wealth constrained $(B C 2)$, to be just income constrained $(B B C)$, to be just wealth constrained $(W B C)$, and to be credit constrained measured with direct responses from the surveyed households (DCC). Additionally, as we anticipated, the estimated coefficients for the effect of income constraints are highly biased in the univariate probit models with respect to the bivariate models, and we find an upward bias around $27 \%,-2.17$ vs. -1.58 , and -2.44 vs. -1.79 in $B C 1$ and $B C 2$ (model 1 to 4), respectively, and a downward bias around $105 \%$ in $I B C,-0.38$ vs. -0.78 , and around $20 \%$ in $W B C,-3.33$ vs. -4.03 (model 5 to 8 ). Turning our attention to our theoretical tenure choice equation (3), as it predicts and consistently with previous empirical evidence, we observe a significant negative effect of labor income uncertainty on the probability of homeownership of the Italian households. However, there are marked differences across models. Focusing on the consistently estimated coefficients in the bivariate probit models, these range from -0.56 in model 4 to -0.31 in model 8.

Other differences across models are also observed in the effect of some variables considered in the owner-occupancy equation, but the signs persistently remain in all models. Owner-occupancy is more likely in smaller cities (less than 500,000 inhabitants), and out of the city center and in isolated areas. As expected, household head age, family income and being married raise the propensity to own, whereas education and household size exert a negative effect. This result is contrary to what one should expect.

In table 8 we show our major findings of the bivariate probit models with sample selection. To facilitate interpretation and the comparison between alternative models, besides estimated coefficients we also report the marginal effects. Given that ours is a two-equation system, to compute marginal effects of a variable in both equations would require the calculation of marginal effects. However, our variable of interest, labor income uncertainty, is just present in the homeownership equation, therefore, marginal effects for this variable can be computed straightforward as in a univariate probit model (see Christofides et al. 1997), $\phi_{i}\left(X_{i 2} \beta_{2}+R_{i 2} \gamma_{2}\right) \cdot \gamma_{2}$, where $\phi$ is the standard normal density and $\gamma_{2}$ is the parameter associated to the labor income uncertainty.

We have estimated the effect of income uncertainty on the probability of homeownership for different population groups depending on whether they are or not credit constrained, and whether they are or not risk averse. These results are crucial to determine the nature of the 
negative relationship between homeownership and labor income uncertainty. First at all, we shall remark that the highly statistical significance of the correlation terms suggests that controlling for sample selection is critical to obtain unbiased estimates of the labor income uncertainty effect on the owner-occupancy propensities. We just show the effects concerning labor income uncertainty in the homeownership equation.

Differences in the effect of income uncertainty on the probability of homeownership between credit and non-redit constrained are practically negligible. Indeed for non-wealth constrained $(W B C)$ and for simultaneously non-wealth and non-income constrained $(B C 2)$ households, the negative effect of income uncertainty is slightly higher. Major differences in this negative relationship are reported by risk aversion. A $10 \%$ increase in the average labor uncertainty decreases a $-3.25 \%$ the probability to be homeowner, whereas for non-risk averse households this effect is statistically insignificant. On the contrary, the major differences regarding credit constraints are reported by the income constraints variable (IBC), from $2.95 \%$ for income constrained households to $-2.41 \%$ for the non-income constrained. In both cases, estimated coefficients are highly significant. As we ruled in our theoretical model, these results support the hypothesis that the negative relationship between labor income uncertainty and the likelihood of being homeowner is driven by risk-aversion.

\section{Conclusions and discussion}

It is well known that there exist a number of barriers to access homeownership, and this issue have been widely studied in the economic literature. This responds to the concerns of policy makers, since this issue has been a policy objective during many years. Although this debate is from general interest in all developed economies, empirical research mainly focus on the US. In this study we aimed at disentangling the puzzle behind the negative relationship between labor income uncertainty and homeownership. We test for the first time the role of credit constraints vs. risk aversion on such a negative relationship, and we observe that it is driven by risk-aversion, whereas credit constraints plays no relevant role. Additionally, we also remark two important results. First, in accordance with the previous evidence in the US and Australia we observe that in Italy credit constraints are also an important barrier to homeownership. We reach this conclusion by using both Linneman and Wachter's (1989) and Rosenthal's (2002) definition of being credit constrained. And Second, according to the observed in the US, Germany and Spain, we also observe a significant negative effect of labor 
income uncertainty on the owner-occupancy tendencies across Italian households. This result is in itself relevant given the ambiguity of the theoretical models analyzing this effect.

Turning to the main goal of the paper, that is. the nature of the negative effect of income uncertainty on homeownership. Our measure of risk aversion has been tested and has showed a good performance. We have also accounted for sample selection and other potential sources of bias that might obscure the true relationship between income uncertainty and homeownership. Therefore, we support the robustness of our results. The crucial role of risk aversion suggests that the "fear" that a risk averse household facing increasing income uncertainty to a mortgage default is stronger than the reluctance of the credit industry to fund this households.

The policy implications of our findings question whether relaxing the mortgage industry (e.g. lower down payments or longer amortization periods) is enough in itself to promote homeownership across risk averse household facing higher volatility in their incomes. This questioning emerges from the fact that volatile incomes are not necessarily related to lowincomes. Indeed, some empirical evidence shows that, on average, riskier incomes are associated to higher incomes ${ }^{11}$. In this sense, more efficient mortgage insurance products or a more steady labor market is, undoubtedly, a better way to promote homeownership. Given the relevance of the subject, more international research in this issue is encouraged.

\footnotetext{
${ }^{11}$ See McGoldrick (1995) in the US, Hartog et al. (2003) in Spain, Germany, The Netherlands and Portugal, and Diaz-Serrano et al (2003) in Denmark.
} 


\section{References}

Barakova I., Bostic R.W., Calem P.S., Wachter S.M., 2003. Does Credit Quality Matter for Homeownership?. Journal of Housing Economics 12 (4), pp. 318-336.

Bourassa S.C., 1995. The Impacts of Borrowing Constraints on Home-Ownership in Australia. Urban Studies 32 (7), pp. 1163-1173.

Brunello G., 2002. Absolute Risk Aversion and the Returns to Education. Economics of Education Review 21 (6), pp. 635-640.

Christofides L.N., Stengos T., Swidinsky R., 1997. On the Calculation of Marginal Effects in the Bivariate Probit Model, Economics Letters 54 (3), pp. 203-208.

Diaz-Serrano L., Hartog J., Nielsen H.S., 2003. Compensating Wage Differentials for Schooling Risk in Denmark, IZA discussion papers \#963, Bonn, Germany.

Diaz-Serrano L., 2004. Labor Income Uncertainty, Risk-Aversion and Homeownership. IZA discussion paper \#1008, Bonn, Germany.

Fu Y., 1995. Uncertainty, Liquidity, and Housing Choices. Regional Science and Urban Economics 25 (2), pp. 223-236.

Guiso L., Paiella M., 2001. Risk Aversion, Wealth and Background Risk CEPR discussion paper \#2728, London, UK.

Hartog J., Ferrer-i-Carbonell A., Jonker N., 2002. Linking Measured Risk Aversion to Individual Characteristics. Kyklos 55 (1), pp. 3-26.

Hartog J., Plug E.J.S., Diaz-Serrano L., Vieira A.J.C., 2003. Risk Compensation in Wages: a Replication, Empirical Economics 28 (3), pp. 639-647.

Haurin D.R., Hendershott P.H., Wachter S.M., 1997. Borrowing Constraints and the Tenure Choice of Young Households. Journal of Housing Research 8 (2), pp. 137-154.

Haurin, D.R., Gill H.L., 1987. Effects of Income Variability on the Demand for OwnerOccupied Housing. Journal of Urban Economics 22 (2), pp. 136-150.

Haurin, D.R.., 1991. Income Variability, Homeownership, and Housing Demand. Journal of Housing Economics 1 (1), pp. 60-74.

Hsiao C., 1986. Analysis of panel data. Cambridge University Press, Cambridge.

Linneman P.D., Wachter S.M., 1989. The Impacts of Borrowing Constraints on Homeownership. AREUEA Journal 17 (4), pp. 389-402.

McGoldrick K., 1995. Do Women Receive Compensating Wages for Earnings Uncertainty?, Southern Economics Journal 62 (1), pp. 210-222. 
Ortalo-Magne, F., Rady, S., 2002. Tenure Choice and the Riskiness of Non-housing Consumption. Journal of Housing Economics 11 (3), pp. 266-279.

Pryce G., Keoghan M., 2002. Unemployment Insurance for Mortgage Borrowers: Is It Viable and Does It Cover Those Most in Need? European Journal of Housing Policy 2 (1), pp. 87-114.

Quercia, R.G., McCarthy G.W., Wachter S.M., 2003. The Impacts of Affordable Lending Efforts on Homeownership Rates. Journal of Housing Economics 12 (1), pp. 29-59.

Robst, J., Deitz, R., McGoldrick K., 1999. Income Variability, Uncertainty and Housing Tenure Choice. Regional Science and Urban Economics 29 (2), pp. 219-229.

Rosenthal S.S., 2002. Eliminating Credit Barriers: How Far Can We Go?. In: Retsinas N.P., Belsky E.S. (Eds.), Low-Income Homeownership, pp. 111-145.

Turnbull, G.K., Glascock, J.L., Sirmans, C.F., 1991. Uncertain Income and Housing Price and Location Choice. Journal of Regional Science 31 (4), pp. 417-433.

Wooldbridge, J.W., 2002. Econometric Analysis of Cross Section and Panel Data. MIT Press, Cambridge. 


\section{Annex of tables}

Table 1

Variable description

\begin{tabular}{|c|c|}
\hline Variable name & Description \\
\hline Owner & Dummy takes 1 if the household is owner-occupier \\
\hline Age & Age of the household head \\
\hline Household size & Number of individuals living in the household \\
\hline Married & Dummy takes 1 if the household head is married \\
\hline Dependent & Number of household members without earnings \\
\hline Years of schooling & Education of the household head \\
\hline Self-employment & Dummy takes 1 if the household head is self-employed \\
\hline Unemployed & Dummy takes 1 if the household head is unemployed \\
\hline Household income & Sum of annual net earnings for all household members \\
\hline Rent $/ \mathrm{m}^{2}$-Owning $/ \mathrm{m}^{2}$ & Gap between monthly rent and monthly mortgage payment per $\mathrm{m}^{2}$ \\
\hline Location & $\begin{array}{l}\text { Dummies take } 1 \text { if the dwelling is located in Isolated area, town outskirts, } \\
\text { between town outskirts or city center, or in city center }\end{array}$ \\
\hline City size & $\begin{array}{l}\text { Dummy takes } 1 \text { if the for the following city size categories: less than } 20,000 \text {; } \\
\text { between } 20,000 \text { and } 40,000 \text {; between } 40,000 \text { and 500,000; more than 500,000 }\end{array}$ \\
\hline DCC & $\begin{array}{l}\text { Dummy takes } 1 \text { if any member of the household have not received full grant } \\
\text { for a credit or this has been rejected. Or if any of the member has decided do } \\
\text { not apply for a credit concerned that this could be rejected. }\end{array}$ \\
\hline IBC & Dummy takes 1 if the household is income constrained \\
\hline WBC & Dummy takes 1 if the household is wealth constrained \\
\hline BC1 & Dummy takes 1 if the household is wealth or income constrained \\
\hline $\mathrm{BC} 2$ & Dummy takes 1 if the household is either wealth and income constrained \\
\hline Outstanding bank debt & $\begin{array}{l}\text { Dummies take1 if the household has outstanding debt for the purchase of real } \\
\text { goods, motor vehicles, furniture or electrical appliances, and non durable } \\
\text { goods }\end{array}$ \\
\hline Region (5 regions) & $\begin{array}{l}\text { Dummies take } 1 \text { for the following regional locations (North-East, North-West, } \\
\text { Center, South and Islands }\end{array}$ \\
\hline Region (20 regions) & Dummies take 1 for the 20 Italian regions \\
\hline Experience & Potential years of working experience of the household head \\
\hline Year & Dummies for 1995 and 1998 \\
\hline ARA & Nonparametric measure of risk aversion \\
\hline Risk averse & Dummy takes one if ARA $>0$ \\
\hline
\end{tabular}


Table 2

Estimation of the house preferred value according to equation (5), and of the labor income equation (6)

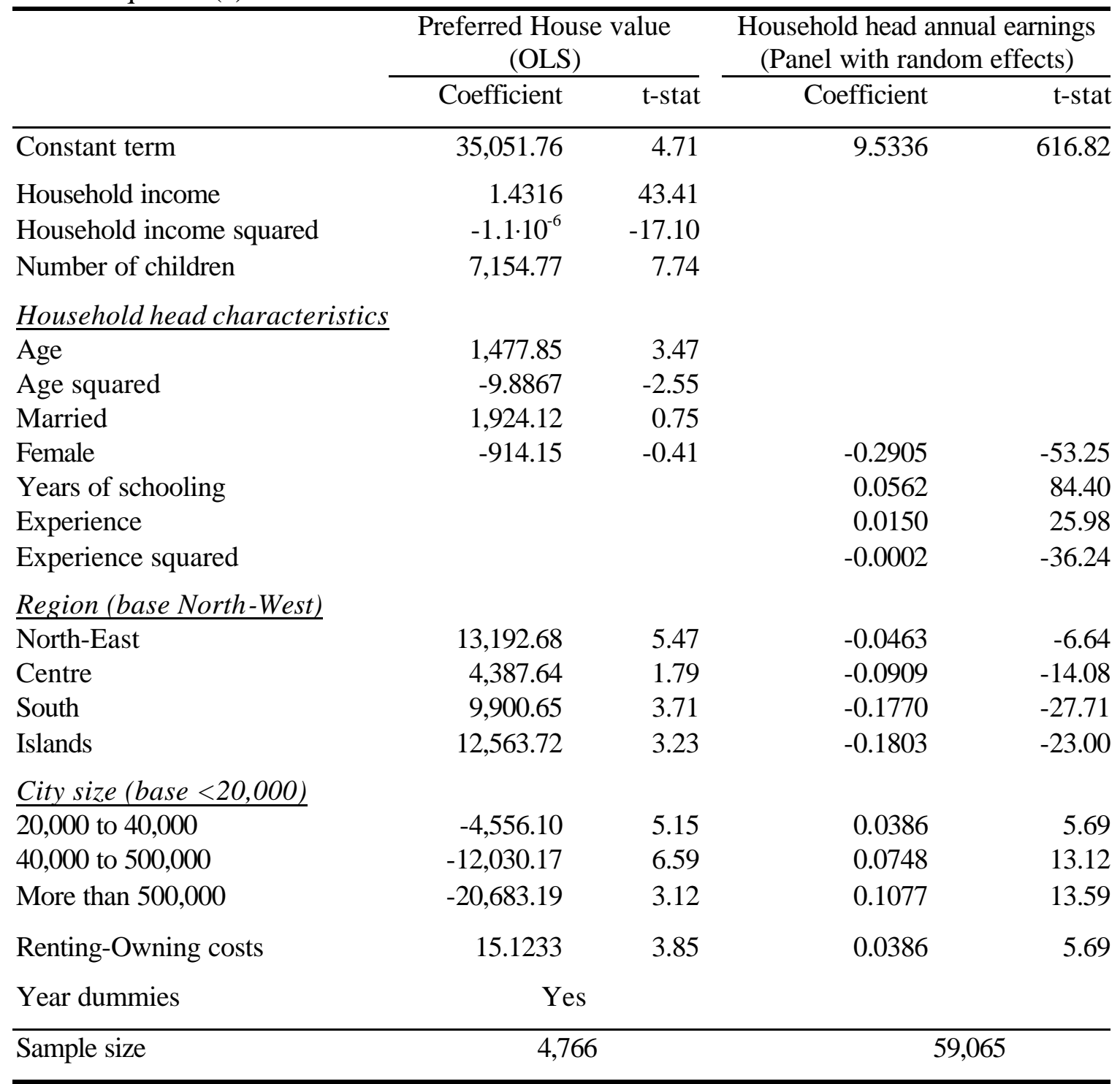


Table 3

Sample means for borrowing constraints variables

\begin{tabular}{|c|c|c|c|c|c|c|c|c|c|}
\hline & \multicolumn{3}{|c|}{$\begin{array}{c}\text { Wealth Constrained } \\
(W B C)\end{array}$} & \multicolumn{3}{|c|}{$\begin{array}{c}\text { Income Constrained } \\
(I B C)\end{array}$} & \multicolumn{3}{|c|}{$\begin{array}{l}\text { Wealth and Income } \\
\text { Constrained }(B C 2)\end{array}$} \\
\hline & full & renter & owner & full & renter & owner & full & renter & $\overline{\text { owner }}$ \\
\hline Total & 0.243 & 0.792 & 0.014 & 0.378 & 0.514 & 0.321 & 0.138 & 0.443 & 0.011 \\
\hline \multicolumn{10}{|l|}{ Household head age } \\
\hline Up to 30 & 0.441 & 0.831 & 0.008 & 0.362 & 0.479 & 0.231 & 0.211 & 0.400 & 0.003 \\
\hline $31-40$ & 0.316 & 0.767 & 0.009 & 0.324 & 0.436 & 0.247 & 0.148 & 0.359 & 0.005 \\
\hline $41-50$ & 0.228 & 0.744 & 0.006 & 0.303 & 0.441 & 0.244 & 0.113 & 0.364 & 0.004 \\
\hline $51-65$ & 0.177 & 0.766 & 0.009 & 0.331 & 0.481 & 0.288 & 0.096 & 0.411 & 0.007 \\
\hline more than 65 & 0.249 & 0.870 & 0.029 & 0.526 & 0.699 & 0.464 & 0.187 & 0.640 & 0.026 \\
\hline \multicolumn{10}{|l|}{ Region } \\
\hline$\overline{\text { North-West }}$ & 0.262 & 0.785 & 0.003 & 0.250 & 0.388 & 0.181 & 0.114 & 0.342 & 0.001 \\
\hline North-East & 0.215 & 0.794 & 0.011 & 0.326 & 0.487 & 0.269 & 0.115 & 0.420 & 0.008 \\
\hline Centre & 0.214 & 0.756 & 0.006 & 0.316 & 0.438 & 0.269 & 0.105 & 0.365 & 0.004 \\
\hline South & 0.266 & 0.830 & 0.026 & 0.527 & 0.668 & 0.468 & 0.188 & 0.582 & 0.020 \\
\hline Islands & 0.254 & 0.790 & 0.035 & 0.574 & 0.701 & 0.522 & 0.195 & 0.591 & 0.034 \\
\hline \multicolumn{10}{|l|}{ City size } \\
\hline$\overline{\text { Up to } 20,000}$ & 0.208 & 0.807 & 0.022 & 0.475 & 0.594 & 0.438 & 0.137 & 0.518 & 0.019 \\
\hline 20,000 to 40,000 & 0.221 & 0.775 & 0.010 & 0.395 & 0.540 & 0.341 & 0.130 & 0.452 & 0.008 \\
\hline 40,000 to 500,000 & 0.261 & 0.801 & 0.012 & 0.336 & 0.499 & 0.261 & 0.141 & 0.429 & 0.009 \\
\hline more than 500,000 & 0.298 & 0.762 & 0.004 & 0.258 & 0.403 & 0.165 & 0.142 & 0.360 & 0.004 \\
\hline
\end{tabular}


Table 4

Sample means for labor income uncertainty

\begin{tabular}{lccc}
\hline & Full sample & Renter & Owner \\
\hline Total & 0.264 & 0.373 & 0.263 \\
Household head age & & & \\
Up to 30 & 0.416 & & 0.416 \\
$31-40$ & 0.248 & 0.029 & 0.249 \\
$41-50$ & 0.230 & 0.348 & 0.228 \\
$51-65$ & 0.292 & 0.422 & 0.290 \\
more than 65 & 0.279 & 0.429 & 0.274 \\
Married & 0.260 & 0.396 & 0.258 \\
Not married & 0.284 & 0.283 & 0.285 \\
Self-employed & 0.450 & 0.552 & 0.228 \\
Not self-employed & 0.230 & 0.345 & 0.373 \\
Unemployed & 0.450 & & 0.450 \\
Not unemployed & 0.261 & 0.373 & 0.260 \\
Region & & & \\
North-West & 0.241 & 0.056 & 0.244 \\
North-East & 0.272 & 0.295 & 0.271 \\
Centre & 0.249 & & 0.249 \\
South & 0.260 & 0.427 & 0.254 \\
Islands & 0.330 & 0.777 & 0.322 \\
\hline
\end{tabular}

Table 5

Sample statistics for risk aversion

\begin{tabular}{lcccccc}
\hline & \multicolumn{2}{c}{$\mathbf{1 9 9 5}$} & & \multicolumn{2}{c}{$\mathbf{2 0 0 0}$} \\
\cline { 2 - 3 } \cline { 6 - 7 } & $\mathrm{N}$ & $\%$ & & $\mathrm{~N}$ & $\%$ \\
\hline Answered the question & 5,814 & 71,5 & & 3,193 & 81.2 \\
Did not answer the question & 2,321 & 28,5 & & 740 & 18.8 \\
Total respondents & 8,135 & & & 3,933 & \\
\cline { 2 - 3 } & $(1)$ & $(2)$ & & $(1)$ & $(2)$ \\
\hline Risk Averse (P<2,600€) & $86.3 \%$ & $76.5 \%$ & & $97.2 \%$ & $92.4 \%$ \\
Risk Neutral $(\mathrm{P}=2,600 €)$ & $9.9 \%$ & $16.9 \%$ & & $2.5 \%$ & $6.8 \%$ \\
Risk Lovers (P>2,600€) & $3.8 \%$ & $6.6 \%$ & & $0.3 \%$ & $0.8 \%$ \\
\hline
\end{tabular}

Note: (1) Including all valid responses; (2) Including only positive responses. 
Table 6

Performance tests for absolute risk aversion (ARA)

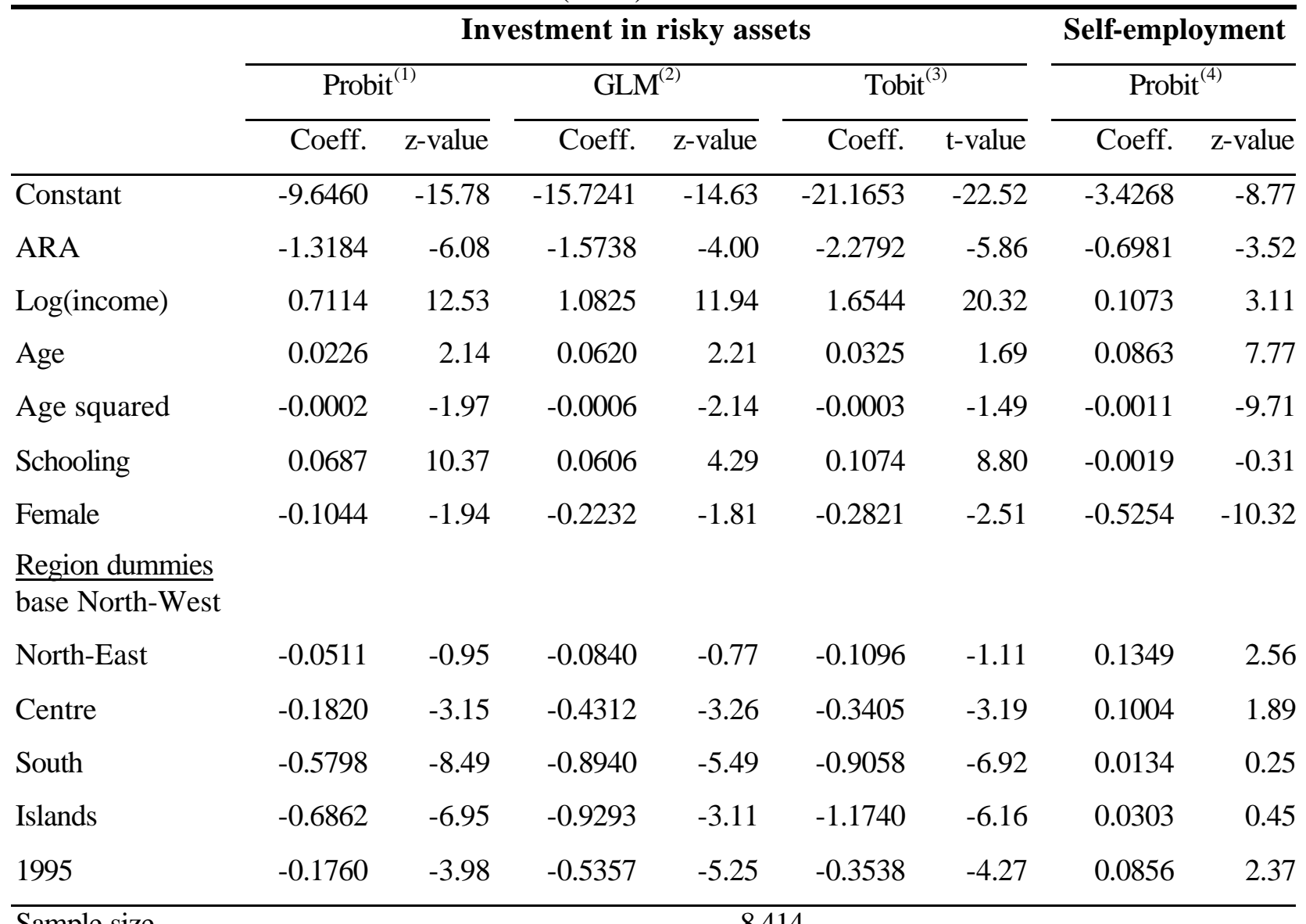

Sample size

8,414

Note: (1) Endogenous variable: Dummy takes 1 if the household has risky asset in the portfolio; (2) Endogenous variable: Percentage of investment in risky assets overall portfolio. In the generalized linear model I use a logit function on the endogenous variable; (3) Endogenous variable: Total amount invested in risky assets. Truncation point at 0; (4) Endogenous variable: Dummy takes one if the household head is self-employee. 
Table 7

Estimation of homeownership equations (bivariate and univariate probits)

\begin{tabular}{|c|c|c|c|c|c|c|c|c|c|c|c|c|}
\hline & \multicolumn{2}{|c|}{$\begin{array}{l}\begin{array}{l}\text { Univariate Probit } \\
\text { (Model 1) }\end{array} \\
\text { Homeownership }\end{array}$} & \multicolumn{4}{|c|}{$\begin{array}{c}\text { Bivariate Probit } \\
\text { (Model 2) }\end{array}$} & \multicolumn{2}{|c|}{$\begin{array}{l}\begin{array}{l}\text { Univariate Probit } \\
\text { (Model 3) }\end{array} \\
\text { Homeownership }\end{array}$} & \multicolumn{4}{|c|}{$\begin{array}{c}\text { Bivariate Probit } \\
\text { (Model 4) }\end{array}$} \\
\hline & Coeff. & z-stat & Coeff. & z-stat & Coeff. & z-stat & Coeff. & z-stat & Coeff. & z-stat & Coeff. & z-stat \\
\hline Age & -0.0301 & -3.22 & -0.0293 & -3.20 & 0.0125 & 8.37 & -0.0211 & -2.10 & -0.0166 & -1.71 & 0.0127 & 6.88 \\
\hline Age squared & 0.0002 & 2.73 & 0.0002 & 2.55 & & & 0.0002 & 1.81 & 0.0001 & 1.26 & & \\
\hline Household size & -0.0856 & -4.01 & -0.0771 & -3.67 & & & -0.1145 & -5.20 & -0.1080 & -4.98 & & \\
\hline Married & 0.2789 & 5.06 & 0.2814 & 5.24 & & & 0.2639 & 4.76 & 0.2764 & 5.12 & & \\
\hline Self-employed & 0.0633 & 1.02 & 0.0825 & 1.38 & -0.2275 & -3.91 & 0.0814 & 1.51 & 0.0945 & 1.75 & -0.6791 & -7.06 \\
\hline Income uncertainty & -0.4169 & -4.47 & -0.4169 & -4.26 & & & -0.5904 & -6.20 & -0.5687 & -5.67 & & \\
\hline Family income & $1.0 \cdot 10^{-6}$ & 1.10 & 0.0000 & 2.20 & $-4.2 \cdot 10^{-5}$ & -24.36 & $8.9 \cdot 10^{-6}$ & 6.94 & $1.1 \cdot 10^{-5}$ & 6.05 & $-8.3 \cdot 10^{-5}$ & -27.98 \\
\hline Rent/m2 - Owning/m2 & 0.0003 & 1.80 & 0.0003 & 2.05 & & & 0.0005 & 3.22 & 0.0005 & 3.46 & & \\
\hline \multicolumn{13}{|l|}{ Location dummies (base-others) } \\
\hline$\overline{\text { Isolated }- \text { countryside }}$ & 0.2135 & 1.58 & 0.2000 & 1.53 & & & 0.1302 & 0.99 & 0.1267 & 0.99 & & \\
\hline$>500.000$ inhab. & -0.4864 & -7.59 & -0.4710 & -7.50 & & & -0.4021 & -6.81 & -0.3964 & -6.84 & & \\
\hline \multicolumn{13}{|l|}{ Credit constraints } \\
\hline$\overline{\mathrm{DCC} \text { (Direct answer from respondents) }}$ & -0.3611 & -2.82 & -0.3336 & -2.72 & & & -0.6002 & -4.95 & -0.5837 & -4.83 & & \\
\hline BC1 (Income or wealth constrained) & -2.1783 & -40.10 & -1.5865 & -6.95 & & & & & & & & \\
\hline BC2 (Income and wealth constrained) & & & & & & & -2.4447 & -28.66 & -1.7977 & -8.36 & & \\
\hline \multicolumn{13}{|l|}{ Outstanding bank debt dummies } \\
\hline$\overline{\text { Purchase of real goods }}$ & & & & & -0.2660 & -0.63 & & & & & 0.1379 & 0.19 \\
\hline Purchase of motor vehicles & & & & & -0.0364 & -0.53 & & & & & -0.0475 & -0.45 \\
\hline Purchase of furniture, electrical appliances & & & & & 0.1365 & 1.47 & & & & & 0.2608 & 2.24 \\
\hline Purchase of non-durable goods & & & & & 0.0442 & 0.25 & & & & & 0.5570 & 2.28 \\
\hline$\rho$ & & & & & & 0.3561 & & & & & & $\overline{0.4331}$ \\
\hline Wald test $\mathrm{H}_{0}: \rho=0$ & & & & & & 8.917 & & & & & & 13.47 \\
\hline
\end{tabular}

Note: All the equations include year and regional (20 regions) dummies; $\mathrm{BC} 1$ : households either income or wealth constrained; BC2: households both income and wealth constrained. 
Table 7

(continuation)

\begin{tabular}{|c|c|c|c|c|c|c|c|c|c|c|c|c|}
\hline & \multicolumn{2}{|c|}{$\begin{array}{l}\text { Univariate Probit } \\
\text { (Model 5) } \\
\text { Homeownership }\end{array}$} & \multicolumn{4}{|c|}{$\begin{array}{l}\text { Bivariate Probit } \\
\text { (Model 6) }\end{array}$} & \multicolumn{2}{|c|}{$\begin{array}{l}\text { Univariate Probit } \\
\text { (Model 7) } \\
\text { Homeownership }\end{array}$} & \multicolumn{4}{|c|}{$\begin{array}{l}\text { Bivariate Probit } \\
\text { (Model 8) }\end{array}$} \\
\hline & Coeff. & z-stat & Coeff. & z-stat & Coeff. & z-stat & Coeff. & z-stat & Coeff. & z-stat & Coeff. & z-stat \\
\hline Age & -0.0160 & -1.86 & -0.0188 & -2.25 & 0.0158 & 8.64 & -0.0503 & -3.70 & -0.0481 & -4.06 & 0.0090 & 6.87 \\
\hline Age squared & 0.0001 & 1.11 & 0.0001 & 1.63 & & & 0.0004 & 3.21 & 0.0004 & 3.79 & & \\
\hline Household size & -0.1056 & -5.25 & -0.1069 & -5.53 & & & -0.1015 & -3.65 & -0.1136 & -4.61 & & \\
\hline Married & 0.2942 & 6.04 & 0.2640 & 5.53 & & & 0.3137 & 4.18 & 0.2572 & 3.79 & & \\
\hline Self-employed & 0.1738 & 3.36 & 0.1939 & 3.77 & 0.0960 & 1.24 & -0.3650 & -5.55 & -0.4545 & -7.04 & -0.4621 & -7.62 \\
\hline Income uncertainty & -0.5466 & -5.55 & -0.5239 & -5.95 & & & -0.2968 & -2.73 & -0.3123 & -3.46 & & \\
\hline Family income & $1.2 \cdot 10^{-5}$ & 7.04 & $9.3 \cdot 10^{-6}$ & 5.91 & -0.0001 & -38.89 & $3.9 \cdot 10^{-6}$ & 3.01 & $8.8 \cdot 10^{-7}$ & 0.87 & $-2.3 \cdot 10^{-5}$ & -19.23 \\
\hline Rent/m2 - Owning/m2 & 0.0005 & 3.26 & 0.0004 & 2.67 & & & 0.0003 & 1.74 & 0.0002 & 1.34 & & \\
\hline \multicolumn{13}{|l|}{ Location dummies (base-others) } \\
\hline Isolated - countryside & 0.2208 & 1.95 & 0.2294 & 2.07 & & & & & 0.0420 & 0.24 & & \\
\hline >500.000 inhab. & -0.3676 & -6.60 & -0.3456 & -6.34 & & & & & & & & \\
\hline \multicolumn{13}{|l|}{ Credit constraints } \\
\hline 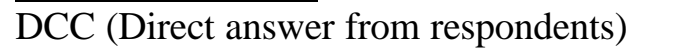 & -0.4970 & -4.43 & -0.4917 & -4.49 & & & -0.4963 & -3.10 & -0.4476 & -3.27 & & \\
\hline IBC (Income constrained) & -0.3881 & -5.93 & -0.7887 & -9.94 & & & & & & & & \\
\hline WBC (Wealth constrained) & & & & & & & -3.3366 & -45.26 & -4.0331 & -51.64 & & \\
\hline \multicolumn{13}{|l|}{ Outstanding bank debt dummies } \\
\hline Purchase of real goods & & & & & -0.1362 & -0.22 & & & & & 0.2077 & 0.63 \\
\hline Purchase of motor vehicles & & & & & -0.1321 & -1.38 & & & & & 0.1401 & 2.35 \\
\hline Purchase of furniture, electrical appliances & & & & & 0.2601 & 2.17 & & & & & 0.2290 & 2.88 \\
\hline Purchase of non-durable goods & & & & & 0.2742 & 0.92 & & & & & 0.4807 & 2.96 \\
\hline$\rho$ & & & & & & 0.4485 & & & & & & $\overline{0.7874}$ \\
\hline Wald test $\mathrm{H}_{0}: \rho=0$ & & & & & & 55.56 & & & & & & 9.94 \\
\hline
\end{tabular}

Note: All the equations include year and regional (20 regions) dummies; BC1: households either income or wealth constrained; $\mathrm{BC} 2$ : households both income and wealth constrained. 
Table 8

Estimated coefficients for labor income uncertainty in the homeownership equation

(univariate probits for selected groups and bivariate probits with sample selection)

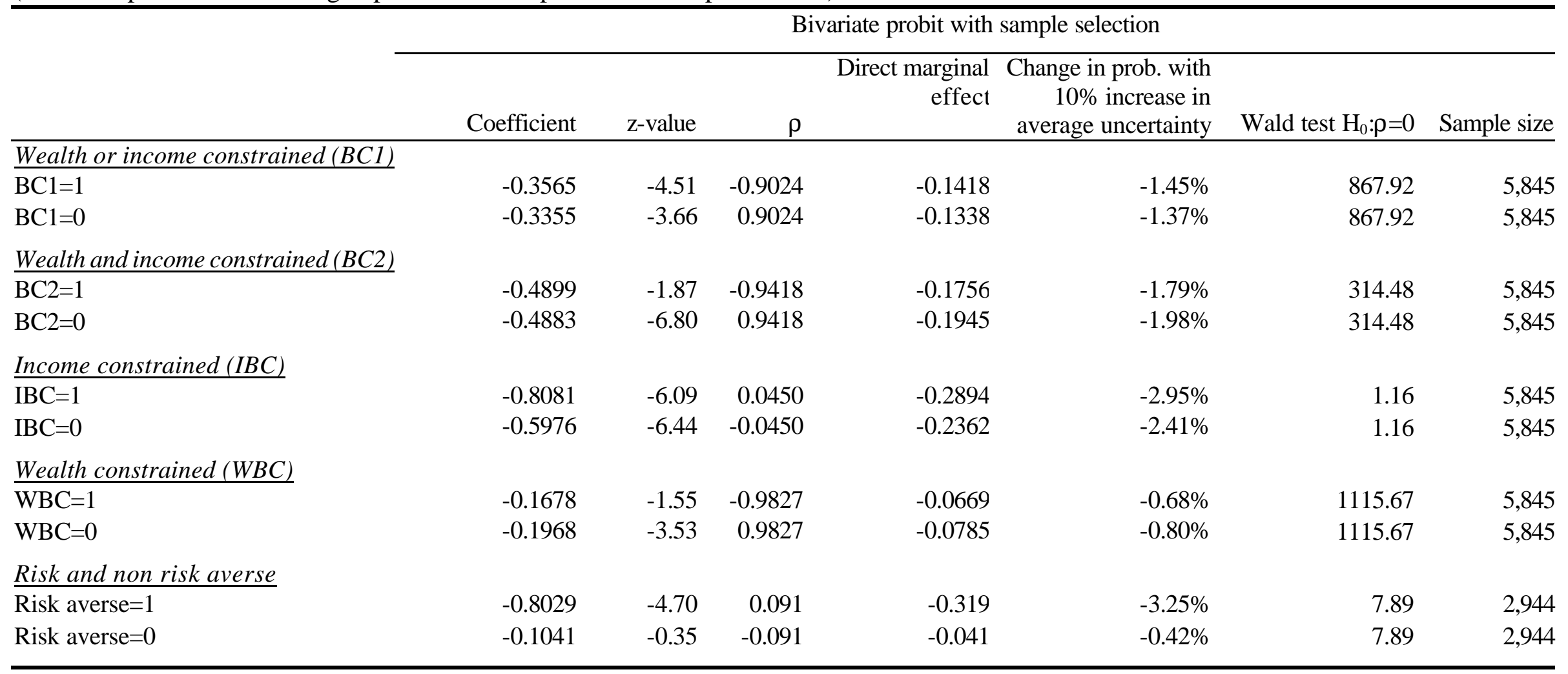

